\title{
Biomedical Waste Management: A Review
}

\author{
Sunil Kumar VC', Manjunatha. M², Badami Vijetha ${ }^{3}$, Pradeep P.R. ${ }^{4}$
}

\begin{abstract}
Various national and international agencies have shown their concern towards proper handling, treatment and disposal of biomedical waste, as they may cause serious infectious diseases like hepatitis, tuberculosis and HIV/AIDS. Most of the hospitals do not have effective disposal system leading to complex problem of hygiene and sanitation in hospitals. The use of disposable items has reduced the rate of infection but at the same time has increased the volume of the waste which needs to be disposed properly. Effective waste disposal can be achieved only by considering the various components of the waste management system and this should be made an integral part of hospital planning and designing.
\end{abstract}

Key words: Bio-medical waste (bmw), Segregation, Disposal, Waste handler, Dental waste.

${ }^{1}$ Professor

Dept. of Conservative Dentistry and Endodonics Bhabha College of Dental Sciences,

Bhopal (MP), India

${ }^{2}$ Reader

Dept. of Conservative Dentistry and Endodonics Bhabha College of Dental Sciences,

Bhopal (MP), India

${ }^{3}$ Professor

Dept. of Conservative Dentistry and Endodontics AME'S Dental College and Hospital,

Raichur, India

${ }^{4}$ Professor

Dept. of Conservative Dentistry and Endodontics MR Ambedkar Dental College and Hospital,

Bangalore, India

\section{Contact Autbor \\ Dr. Sunil Kumar V.C \\ sunilyaar@rediffmail.com}

J Oral Health Comm Dent 2012;6(3)141-144

\section{INTRODUCTION}

Biomedical waste is defined as any solid or liquid waste which may present a threat of infection to humans. It includes non-liquid tissue, body parts, blood, blood products, and body fluids from humans and other primates; laboratory and veterinary wastes which contain human disease-causing agents; and discarded sharps. Also included are the following:

- Used absorbent materials saturated with blood, blood products, body fluids, or excretions or secretions contaminated with visible blood;

- Absorbent materials saturated with blood or blood products that have dried; and

- Non-absorbent disposable devices which have been contaminated with blood, body fluids; or secretions or excretions visibly contaminated with blood.

Common producers of biomedical waste include hospitals, health clinics, nursing homes, medical research laboratories, offices of physicians, dentists, and veterinarians, home health care, and funeral homes. It must be properly managed to protect the general public, specifically healthcare and sanitation workers who are regularly exposed to biomedical waste as an occupational hazard(1).

Biomedical waste management has been in focus in India recently, particularly with the notification of biomedical waste (management and handling) rules, 1998 which was brought out by Union Ministry of Environment and Forests under the provision of Environment (protection) act, 1986. These rules apply to all persons who generate, collect, receive, store, transport, treat, dispose, or handle biomedical waste in any form(2).

\section{OCCUPATIONAL SAFETY AND HEALTH}

In India, occupational safety has always figured low in the priority of employers. This situation needs to be changed, especially in hazardous sectors. The hazards in a hospital environment include the transmission of infections through needle-stick injuries, blood splashes and body fluid spills, mercury poisoning and other chemical exposures. A group of experts should identify problem areas and find ways of minimizing worker exposure. Work involving hazards should be done by the fewest possible number of personnel, and this work 


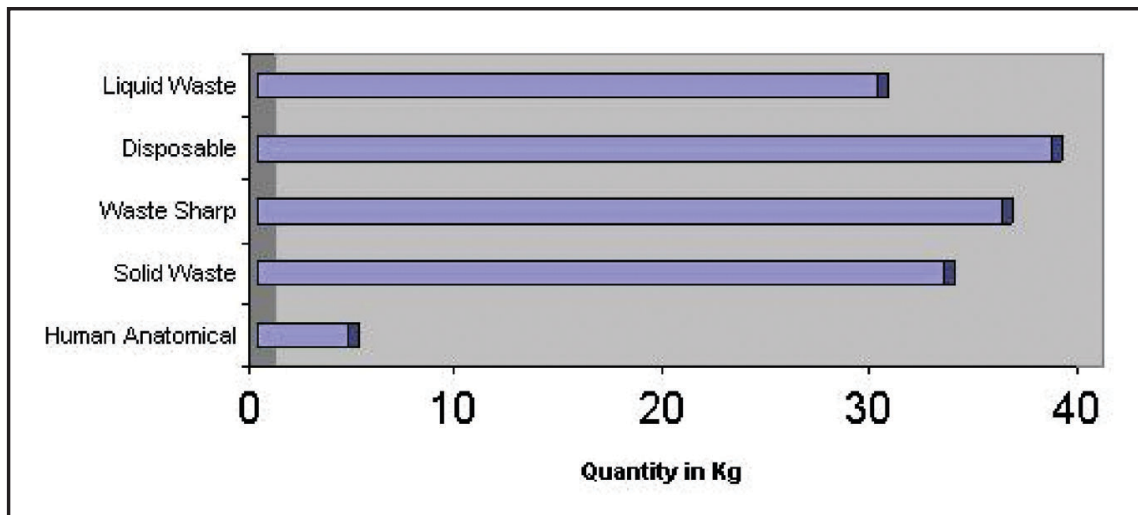

Fig 1 : Chart presentation of Waste generation categories

should be rotated so that the level of exposure to each individual is minimized.

\section{CLASSIFICATION}

- Category No. I: Human anatomical waste. (human tissues, organs, body parts)

- Category No. 2: Animal waste. (animal tissues, organs, body parts, carcasses, bleeding parts, fluid, blood and experimental animals used in research, waste generated by veterinary hospitals, colleges and animal houses)

- Category No. 3: Microbiology \& Biotechnology waste. (wastes from laboratory cultures, stocks or specimens of micro-organisms, live or attenuated vaccines, human and animal cell culture used in research and infectious agents from research and industrial laboratories, wastes from production of biologicals, toxins, dishes and devices used for transfer of cultures)

- Category No. 4: Waste sharps. (needles, syringes, scalpels, blades, glass, etc. that may cause disinfection. This includes both used and unused sharps)

- Category No. 5: Discarded medicines and cytotoxic drugs. (wastes comprising of outdated, contaminated and discarded medicines)

- Category No. 6: Solid waste. (Items contaminated with blood, and body fluids including cotton dressings, soiled plaster casts, lines, beddings, other material)

- Category No. 7: Solid waste. (wastes generated from disposable items other than the waste sharps such as catheters, intravenous sets etc).
- Category No. 8: Liquid waste. (waste generated from laboratory and washing, cleaning, house-keeping and disinfecting activities)

- Category No. 9: Incineration ash. (ash from incineration of any bio-medical waste)

- Category No. 10: Chemical waste. (chemicals used in production of biologicals, chemicals used in disinfection, insecticides, etc.)

\section{MANAGEMENT OF BIO-MEDICAL WASTE}

The collection and transportation of bmw should be carried out in a manner so as to avoid any possible hazard to human health and environment. Collection and transport are the two operations where the chances of segregated bmw coming in contact with public, rag pickers, animals/birds, etc are high. Therefore, all care shall be taken to ensure that the segregated bmw, handed over by the healthcare units, reach treatment facility without any damage, spillage or unauthorized access by public, animals etc. A responsible person from the common biomedical waste treatment facility operator shall always accompany the vehicle to supervise the collection and transport of bmw.

Handling, segregation, mutilation, disinfection, storage, transportation and final disposal are vital steps for safe and scientific management of biomedical waste in any establishment

\section{WASTE SEGREGATION}

The key to minimization and effective management of biomedical waste is segregation (separation) and identification of the waste. The most appropriate way of identifying the categories of bmw is by sorting the waste into color coded plastic bags or containers. Bmw should be segregated into containers/ bags at the point of generation in accordance with Schedule II of Biomedical Waste (management and handling) Rules1998 (2).

General waste like garbage, garden refuse etc. should join the stream of domestic refuse. Sharps should be collected in puncture proof containers. Bags and containers for infectious waste should be marked with biohazard symbol. Highly infectious waste should be sterilized by autoclaving. Cytotoxic wastes are to be collected in leak proof containers clearly labeled as cytotoxic waste. According to various estimates and surveys around $80-90$ percent of hospital waste is general waste and 10-20 per cent is infectious/hazardous. Of this, 15-20 per cent is pathological and infectious waste, one per cent is sharps waste, three per cent chemical/pharmaceutical and less than one per cent is special waste such as radioactive, cytotoxic drugs, etc. (3-5)

\section{WASTE TRANSPORTATION}

Biomedical waste should be transported within the hospital by means of wheeled trolleys, containers or carts that are not used for any other purpose. The trolleys have to be cleaned daily. Off site transportation vehicle should be marked with the name and address of carrier. Biohazard symbol should be painted. Suitable system for securing the load during transport should be ensured. Such a vehicle should be easily cleanable with rounded corners. All disposable plastic should be subjected to shredding before disposing off to ven-

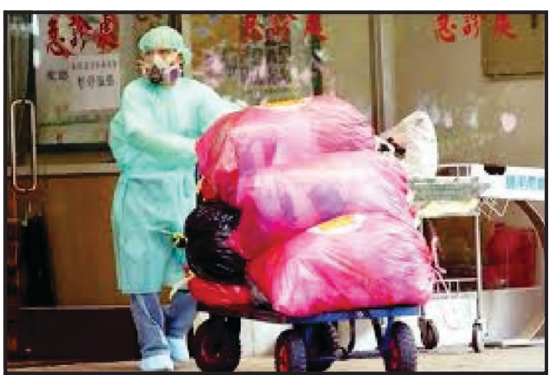


Table 1: Categories of Bio-medical Waste and the Various Disposal Technologies Adopted

\begin{tabular}{|c|c|c|c|c|c|c|c|c|}
\hline $\begin{array}{l}\text { Waste } \\
\text { categories } \\
\text { (Type) }\end{array}$ & $\begin{array}{l}\text { Human wastes } \\
\text { like human } \\
\text { tissues, body } \\
\text { parts. }\end{array}$ & $\begin{array}{l}\text { Animal Wastes } \\
\text { like animal } \\
\text { organs, bleeding } \\
\text { parts, fluids, } \\
\text { waste generated } \\
\text { by veterinary } \\
\text { and animal } \\
\text { hospital. }\end{array}$ & $\begin{array}{l}\text { Microbiology } \\
\text { and } \\
\text { biotechnology } \\
\text { wastes }\end{array}$ & $\begin{array}{l}\text { Waste sharps } \\
\text { like Needles, } \\
\text { Syringes, } \\
\text { blades, } \\
\text { scalpels and } \\
\text { glass waste }\end{array}$ & $\begin{array}{l}\text { Solid wastes } \\
\text { like catheters, } \\
\text { intravenous } \\
\text { sets }\end{array}$ & $\begin{array}{l}\text { Liquid Wastes } \\
\text { generated from } \\
\text { lab, washing, } \\
\text { cleaning, house } \\
\text { keeping and } \\
\text { also disinfecting } \\
\text { activates }\end{array}$ & $\begin{array}{l}\text { Ash from } \\
\text { incineration of } \\
\text { any bio medical } \\
\text { waste }\end{array}$ & $\begin{array}{l}\text { Chemical } \\
\text { waste such as } \\
\text { those used in } \\
\text { production of } \\
\text { biologicals, } \\
\text { disinfections } \\
\text { and } \\
\text { insecticides }\end{array}$ \\
\hline $\begin{array}{l}\text { Treatment } \\
\text { and } \\
\text { Disposal }\end{array}$ & $\begin{array}{l}\text { Incineration/ } \\
\text { deep burial }\end{array}$ & $\begin{array}{l}\text { Incineration/ } \\
\text { deep burial }\end{array}$ & $\begin{array}{l}\text { Local } \\
\text { autoclaving / } \\
\text { incineration, } \\
\text { micro waving }\end{array}$ & $\begin{array}{l}\text { Disinfection by } \\
\text { chemical } \\
\text { treatment/ } \\
\text { autoclaving, } \\
\text { microwaving } \\
\text { and mutilation/ } \\
\text { shredding }\end{array}$ & $\begin{array}{l}\text { Disinfection by } \\
\text { chemical } \\
\text { treatment/ } \\
\text { autoclaving, } \\
\text { microwaving } \\
\text { and mutilation/ } \\
\text { shredding. }\end{array}$ & $\begin{array}{l}\text { Disinfection by } \\
\text { chemical } \\
\text { treatment and } \\
\text { discharge into } \\
\text { drain }\end{array}$ & $\begin{array}{l}\text { Disposal in } \\
\text { municipal } \\
\text { landfill }\end{array}$ & $\begin{array}{l}\text { Chemical } \\
\text { treatment / } \\
\text { discharges } \\
\text { into drains for } \\
\text { liquids and } \\
\text { secured } \\
\text { landfills for } \\
\text { solids }\end{array}$ \\
\hline
\end{tabular}

dor . No untreated bio-medical waste shall be stored beyond a period of 48 hours(3).

\section{TREATMENT EQUIPMENTS}

As per the provision of bmw rules, waste falling in most of the categories can be treated in systems based on nonburn technologies. Such waste account for about $90 \%$ of the waste streams in a health care unit.

\section{INCINERATION}

It is a controlled combustion process where waste is completely oxidized and harmful microorganisms present in it are destroyed/ denatured under high temperature.

\section{AUTOCLAVING/MICROWAVING/ HYDROCLAVING}

Autoclave is a low-heat thermal process where steam is brought into direct contact with waste in a controlled manner and for sufficient duration to disinfect the wastes. It shall have tamper -proof control panel with efficient display and recording devices for critical parameters such as time temperature, pressure, date and batch number etc.
In microwaving, microbial inactivation occurs as a result of the thermal effect of electromagnetic radiation spectrum lying between the frequencies 300 and 300,000 Mhz.. Microwave heating is an inter-molecular heating process. The heating occurs inside the waste material in the presence of steam.

Hydroclaving is similar to that of autoclaving that the waste is subjected to indirect heating by applying steam in the outer jacket. The waste is continuously tumbled in the chamber during this process.

\section{SHREDDER}

Shredding is a process by which waste are deshaped or cut in to smaller pieces so as to make the waste unrecognizable. It helps in prevention of reuse of bmw and also acts as identifier that the waste has been disinfected and safe to dispose off.

\section{SHARP PIT/ENCAPSULATION}

A sharp pit or a facility for sharp encapsulation shall be provided for treatment of sharp. An option may also worked out for recovery of metal from sharps in a factory.

\section{EFFLUENT TREATMENT PLAN}

A suitable effluent treatment plan shall be installed to ensure that liquid effluent generated during the process of washing containers, vehicles, floors etc is disposed after treatment. The treated effluent shall comply with the stipulated regulatory requirements.

\section{COST OF BIOMEDICAL WASTE MANAGEMENT}

The cost of construction, operation and maintenance of system for managing biomedical waste represents a significant part of overall budget of a hospital if the BMW handling rules 1998 have to be implemented in their true spirit. Self-contained on-site treatment methods may be desirable and feasible for large healthcare facilities. They will not be practical or economical for smaller institutes. An acceptable common system should be in place which will provide regular supply of color coded bags, daily collection of infectious waste, safe transportation of waste to off site treatment facility and final disposal with suitable technology. Govt of India in its pilot project for hospital waste manage- 
ment in Govt hospitals has estimated Rs. 85 lakhs as capital cost in 1000 bedded super specialty teaching hospital which includes on site final disposal of BMW(6).

\section{DENTAL WASTES OF ENVIRON- MENTAL CONCERN}

Mercury has a potential to be hazardous if not managed. Therefore, it is important that the alloying reaction of mercury with silver alloy go to completion to ensure that mercury does not diffuse in to oral environment. Once the reaction is complete, only minute amount of mercury can be released and those are far below the current health standards. Scrap dental amalgam from condensation procedures should be collected and stored under water, glycerin, or x-ray fixer in tightly capped jar(7).

X-ray fixer, developer and cleaner solutions are considered a hazardous waste because of its high silver content. In the environment, free ionic silver acts as an enzyme inhibitor by interfering with the metabolic processes of organisms. These have to be disposed off as a hazardous waste or sent to a silver recovery system. The X-ray lead foils and lead shields contain pure lead.
Lead is a heavy metal that affects neurological development and functions and can potentially leach from landfills into the environment. These are hazardous waste unless they are recycled for their scrap metal content or disposed off as hazardous waste(8).

\section{CONCLUSION}

Bio-Medical Waste management programme cannot successfully be implemented without the willingness, devotion, self-motivation, cooperation and participation of all sections of employees of any health care establishment. Therefore, it becomes the responsibility of this group to segregate and manage the waste in such a way, that it is no longer hazard for them, public and environment. Keeping in view, inappropriate management of biomedical wastes, the Ministry of Environment and Forests notified the "Bio Medical Waste (Management and Handling) Rules 1998." These rules are meant to protect the society, patients and health care workers. The most imperative component of the waste management plans is to develop a system and culture through education, training and persistent motivation of the health care staff.

\section{REFERENCES}

1. The management of biomedical waste in Ontario. Legislative authority: Environmental Protection Act, RSO 1990, part V, sections 19 and 27; part XVII, section 197

2. Guidelines for common bio-medical waste treatment facility (august, 2003). Central pollution control board, New Delhi.

3. Bio-medical waste management self learning document for doctors, superintendents and administrators. Environment protection training and research institute Gachibowli, Hyderabad, Andhra Pradesh.

4. NK Das, Sushant Prasad, K Jayaram. A TGM approach to implementation of handling and management of hospital waste in Tata main hospital.

5. Anu G Agrawal, Ratna Singh. Understanding and simplifying biomedical waste management $A$ training manual for trainers. Toxics Link, January 2005.

6. Rao SK, Ranyal RK, Bhatia SS, Sharma VR. Biomedical waste management: An infrastructural survey of hospitals, MJAFI, 2004;60(4).

7. Clifford M, Sturdvant et al. The art and science of operative dentistry $3^{\text {rd }}$ edition.

8. Veda Hedge V. et al. Biomedical waste management: review article. JOMFP 2007;11(1). 